\title{
IMPLEMENTASI HUKUM ISLAM DI INDONESIA \\ DALAM PERSPEKTIF SIYASAH SYAR'IYAH
}

\author{
Maswir \\ Maswir.Wira@gmail.com \\ Universitas Islam Negeri Sultan Syarif Kasim Riau
}

\begin{abstract}
Islamic law is an inseparable part of Islamic teachings, Islamic law is the solution in all life. Because of all the rules that come from God, the purpose is for the benefit of all the people of Russia. However, in its implementation there are still many problems that arise because of the application of Islamic law itself cannot be applied as a whole. Meanwhile, Muslims are scattered in various parts of the world that are not all in the form of an Islamic state. Of course this raises a big problem, because on the one hand of Islam commands that Muslims implement Islamic law in kaphah, on the other hand there are Islamic teachings that cannot be implemented without the involvement of state institutions.
\end{abstract}

Key Words : Islamic law, Siyasah Syar'iyah

\begin{abstract}
Abstrak
Hukum Islam merupakan bagian yang tak terpisahkan dari ajaran Islam, Hukum Islam merupakan solusi dalam segala kehidupan. Dikarenakan segala aturan yang berasal dari Allah swt tujuannya adalah untuk kemaslahatan seluruh umat amnusia. Akan tetapi dalam implementasinya masih banyak menimbulkan persoalan disebakan penerapan hukum Islam itu sendiri belum bisa diterapkan secara menyeluruh. Sementara itu, umat Islam tersebar di berbagai penjuru dunia yang tidak semua dalam bentuk negara Islam. Tentu saja hal ini menimbulkan persoalan besar, karena pada satu sisi Islam memerintahkan agar umat Islam melaksanakan syariat Islam secara kâffah, di sisi lain ada ajaran-ajaran Islam yang tidak dapat dilaksanakan tanpa keterlibatan institusi negara.
\end{abstract}

Kata Kunci: Hukum Islam, Siyasah Syar'iyah 


\section{PENDAHULUAN}

Syariat Islam merupakan bagian yang tak terpisahkan dari ajaran Islam, Syariat Islam merupakan solusi dalam segala kehidupan. Dikarenakan segala aturan yang berasal dari Allah swt tujuannya adalah untuk kemaslahatan seluruh umat amnusia. Akan tetapi dalam implementasinya masih banyak menimbulkan persoalan disebakan penerapan hukum Islam itu sendiri belum bisa diterapkan secara menyeluruh. Sementara itu, umat Islam tersebar di berbagai penjuru dunia yang tidak semua dalam bentuk negara Islam. Tentu saja hal ini menimbulkan persoalan besar, karena pada satu sisi Islam memerintahkan agar umat Islam melaksanakan syariat Islam secara kâffah, di sisi lain ada ajaran-ajaran Islam yang tidak dapat dilaksanakan tanpa keterlibatan institusi negara.

Di Indonesia, polemik penerapan syariat Islam setidaknya tersibak dalam dua kelompok; satu kelompok mengharapkan syariat Islam seluruhnya dapat diadopsi menjadi sumber hukum negara dan diberlakukan bagi para pemeluk Islam, dan kelompok kedua tidak menghendaki seluruh syariat Islam diformalkan dalam konteks negara. Kelompok kedua ini menghendaki negara tidak perlu banyak campur tangan terhadap agama, karena agama sifatnyaindividual. ${ }^{1}$

Menurut Abdurrahman wahid, kelompok pertama memiliki paradigma berfikir "berangkat dengan agama untuk menyelesaikan masalah bangsa", sedang kelompok kedua paradigmanya "berangkat dari agama untuk menyelesaikan masalah-masalah bangsa". ${ }^{2}$ Sungguhpun demikian kedua kelompok ini sebenarnya sama-sama menerima formalisasi syariat Islam pada hukum-hukum privat tertentu. Yang menjadi perdebatan seru di antara kedua kelompok ini adalah ketika persoalannya menyangkut formalisasi syariat secara menyeluruh.Kelompok pertama sangat mendukung, sedang kelompok kedua menolak.Kelompok kedua cukup hukum-hukum privat tertentu saja yang diformalisasikan.

Gagasan pemisahan agama dari negara menurut Soekarno tidak hanya terjadi di Turki, tetapi di negara-negara Eropa seperti Belanda, Perancis, Jerman, Belgia,

\footnotetext{
${ }^{1}$ Paparan lebih jauh dapat dilihat dalam Bahtiar Effendi, Islam dan Negara: Transformasi Pemikiran dan Praktik Politik Islam di Indonesia, (Jakarta:Paramadina, 1998), cet I. hlm. 84-92. Endang Syaifuddin Anshari, Piagam Jakarta 22 Juni 1945, (Bandung: Penerbit Pustaka, 1983), cet. I, hlm. 3.

${ }^{2}$ Abdurrahman Wahid, Islam, Pluralisme dan Demokrasi, dalam Arief Afandi (ed), Islam Demokrasi Atas Bawah, (Jakarta: Pustaka Pelajar, 1996), Cet ke-1, hlm. 110.
} 
Inggris, serta negeri-negeri kolonial yang beragama Islam seperti Indonesia. ${ }^{3}$

Selanjutnya dikemukakan dasar pemikirannya tentang pemisahan agama dari negara dengan mengutip pendapat seorang ulama Al-Azhar (Cairo), Syeikh Ali Abdur Raziq. Pendapat Raziq yang dikutip Soekarno pada dasarnya berprinsip bahwa keharusan bersatunya agama dengan negara tidak ada dasarnya dalam syariat Islam (Al-Qur'an dan Sunnah) maupun ijma ulama, sebab tugas Nabi Muhammad yang terpokok adalah menegakkan syiar Islam tanpa bermaksud mendirikan negara, atau membentuk khilafah yang akan menjadi kepala masyarakatpolitik. Adapun alasan soekarno berpendapat seperti di atas, apabila agama dijadikan alat pemerintah, maka yang terjadi adalah ia akan dijadikan sebagai alat penghukum raja-raja yg zalim, dan tangan besi. ${ }^{4}$

Di lain pihak, Mohammad Natsir sebagai representasi kelompok Islam menolak pendapat Soekarno. Natsir percaya akan watak holistik Islam. ${ }^{5}$ Sebagai seorang ideolog muslim kontemporer Natsir sangat meyakini Islam sebagai suatu ideologi keagamaan. Sebagai suatu ideologi, Islam dalam pandangan Natsir mempunyai cakupan pengertian yang sangat luas, seluas dimensi kehidupanmanusia itu sendiri.Cakupan kehidupan ini tidak hanya meliputi kehidupan dunia tetapi juga kehidupan akhirat. Natsir membantah pendapat soekarno, beliau berpendapat bahwa justru dengan menyatukan agama justru akan mengembangkan negara, karena dengan agama akan bisa menghilangkan perilaku zhalim dan yang sejenis dengannya. ${ }^{6}$

Segala aspek yang terdapat dalam kehidupan dunia dan akhirat itu diatur oleh ajaran-ajaran Islam. Dalam hal ini Natsir mengutip prinsip Al-Qur'an agar seluruh aspek kehidupan di atur secara Islam, sebagaimana dalam firman Allah berikut:

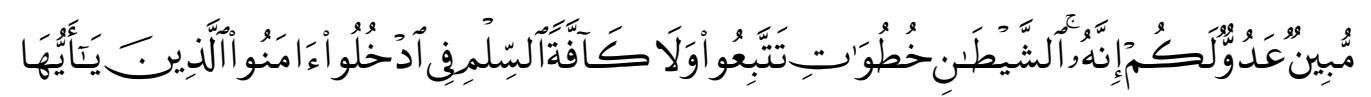

Artinya: Hai orang-orang yang beriman, masuklah kamu ke dalam Islam keseluruhan, dan janganlah kamu turut langkah-langkah syaitan. Sesungguhnya syaitan itu musuh yang nyata bagimu. ${ }^{7}$

Natsir berpendapat bahwa memahami ayat di atas harus totalitas masuk kedalam Islam bahkan sekalipun antara agama dengan negara dan sebaliknya.

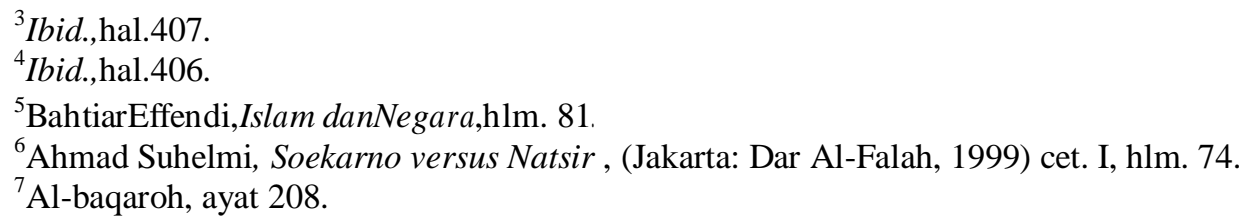


Berdasarkan ayat al qur'an di atas dan pemikiran idiologinya itu, Natsir menolak segala bentuk pemikiran sekuler, sebab pemikiran tersebut mengabaikan nilai-nilai transendental Islam.

Polemik Soekarno dan Natsir masih bersifat eksploratif.Sejak semula keduanya tidak bermaksud untuk merumuskan konsep-konsep yang siap pakai mengenai hubungan antara agama dan negara.Namun keduanya juga tidak bermaksud untuk menemukan titik-titik temu (kalimah sawa') di antara mereka.Keduanya hanya ingin menunjukkan posisi-posisi ideologis-politis masing- masing.Akibatnya, perdebatan-perdebatan itu hanya menggarisbawahi berbagai perbedaan yang tampaknya tak terjembatani antara kedua kelompok politik yang berseberangan.

Mewakili kelompok nasionalis, Soekarno kurang berhasil memberi substansi keagamaan terhadap pandangannya mengenai hubungan Islam dannegara yang telah mengalami "dekonfessionalisasi". Karena itu, meskipun mengimplikasikan paham kaitan non formal atau etis antara Islam dan negara, dalam pandangan banyak aktivis Islam politik, konsepnya sangat dibayang- bayangi oleh semangat "sekularisme" Ataturk, yang disebut dengan nada pejoratif sebagai pemisahan Islam dari negara. Dipihak lain, tanggapan-tanggapan Natsir tampaknya tidak cukup matang. Jawabanjawabannya terhadap tantangan- tantangan Soekarno kurang berhasil mengartikulasikan secara bermakna watak dan bentuk kaitan politik antara Islam dan negara. Malah, ia berhenti pada pernyataan- pernyataan normatif dan umum mengenai Islam yang mungkin mempengaruhi model kaitan antara kedua aras religio-politik ini.

Perdebatan yang cukup panas terjadi manakala BPUPKI mulai membahas persoalan idiologi negara. Kelompok nasionalis bersikeras menjadikan nasionalisme sebagai dasar negara, sedang kelompok Islam menghendaki Islam sebagai dasar negara.Ketegangan tersebut mereda manakala dicapai kesepakatan dibentuknya panitia kecil yang beranggotakan sembilan.Panitia ini secara khusus bertugas untuk merumuskan dasar negara yang terbebas dari wilayah konflik. Panitia kecil ini terdiri dari Soekarno, Mohammad Hatta, A. A. Maramis, Abikoesno Tjokrosoejoso, Abdul Kahar Muzakir, Haji Agus Salim, Achmad Soebarjo, Abdul Wahid Hasyim dan Muhammad Yamin. ${ }^{8}$ Dari panitia kecil ini, setelah melalui perdebatan panjang, dicapai kesepakan rumusan dasar negara yang di dalamnya terdapat rumusan "Percaya

${ }^{8}$ Endang Syaifuddin Anshari, Piagam Jakarta 22 Juni 1945, (Bandung: Penerbit Pustaka, 1983), cet. II, hlm. 26. 
kepada Tuhan dengankewajiban menjalankan syariat Islam bagi pemelukpemeluknya." Rumusan ini dikenal dengan nama "Piagam Jakarta", karena ditandatangani di Jakarta. ${ }^{9}$

Inilah kesuksesan pertama umat Islam dalam memperjuangkan aspirasinya ke dalam negara.Tetapi ternyata kesuksesan ini hanya berlangsung selama 57 hari. ${ }^{10}$ Dua jam menjelang pembacaan teks proklamasi terjadi perubahan besar terhadap apa yang telah dihasilkan dalam sidang-sidang PPKI yang sangat melelahkan. Di antara perubahan itu ialah dihapuskannya Piagam Jakarta dari Preambul Undang-undang Dasar 1945 karena adanya desakan dari kalangan Indonesia Timur. Anak kalimat pengiring yang terdiri dari tujuh atau delapan perkataan di atas dirasakan oleh sebagian bangsa kita di belahan Indonesia Timur sebagai diskriminatif terhadap pemeluk agama lain. ${ }^{11}$ Dengan dihapuskannya Piagam Jakarta dari UUD 1945, pupus sudah harapan umat Islam untuk menjadikan Islam sebagai asas legal-formal segala sendi kehidupan dalam berbangsa danbernegara.

Politik Orde Baru yang represip terhadap aspirasi politik umat Islam berlangsung sampai pertengahan dekade 80-an. Mengendurnya represi terhadap aspirasi politik Islam sebenarnya tidak berdasarkan munculnya kesadaran, melainkan lebih pada pencarian dukungan politik.Sebagaimana diketahui, bahwa pada era-era menjelang tahun 90-an, telah terjadi kebangkitan sosial sebagai akibat semakin cerdasnya umat Islam Indonesia. Kebangkitan tersebut memunculkan tekanan politik baru ketika kelas menengah muslim mendesak representasi yang lebih besar bagi umat Islam dalam pemerintahan dan masyarakat. ${ }^{12}$

Pada akhirnya kebangkitan tersebut memaksa Soeharto mengevaluasi kebijakannya mengenai Islam.Soeharto mulai melunakkan sikapnya terhadap umat Islam dan beberapa kepentingan Islam mulai diakomodasi.Bukti-bukti yang menunjukkan sikap akomodatif negara terhadap Islam mencakup diterapkannya kebijakan-kebijakan yang sejalan dengan kepentingan sosial ekonomi dan politik umat Islam.Setidaknya ada limahal penting yang berhubuangan dengan bentuk akomodatif legislatif negara terhadap Islam:

\footnotetext{
${ }^{9}$ Ibid, hlm, 27.

${ }^{10}$ Safii Maarif, Islam dan Politik, hlm. 29.

${ }^{11}$ Prawoto,PerumusanHistorisRumusDasarNegara,hlm.26.

${ }^{12}$ Robert W. Hefner dalam Ahmad Baso (ed), Civil Islam: Islam dan Demokratisasi di Indonesia, (Jakarta: ISAI, 2001), hlm. 114-115.
} 
1) disahkannya Undang-undang Pendidikan Nasional tahun $1989^{13}$;

2) disahkannya Undang-undang tentang perkawinan tahun 1974.

3) diberlakukannya Undang-undang Peradilan Agama (UUPA) tahun 1989 dan Kompilasi hukum Islam pada tahun 1991;

4) diubahnya kebijakan tentang jilbab tahun 1991;

5) dikeluarkannya surat bersama tingkat menteri berkenaan dengan badan Amil zakat, infak dan shadaqah (BAZIS), dan

6) dihapuskannyaSumbanganDermawanSosialBerhadiah(SDSB)tahun $1993 .{ }^{14}$

7) Sikap akomodatif Orba terhadap Islam semakin kentara dengan dibentuknya Ikatan Cendikiawan Muslim (ICMI) dan didirikannya Bank MuamalatIndonesia.

Keruntuhan Orde Baru pada tahun 1998 memberikan optimisme yang lebih besar lagi kepada umat Islam untuk mewujudkan impiannya membawa syariat Islam ke dalam bentuk yang formal dalam sistem ketatanegaan Indonesia. Kesempatan tersebut langsung digunakan umat Islam dengan membentuk partai- partai Islam.Bahkan MASYUMI sebagai partai masa lalu yang telah dibubarkan Soekarno hidup kembali.Kali ini para elit Islam harus menghadapi kenyataan pahit yang benarbenar didukung oleh fakta-fakta. Ketika suasana politik sedemikian bebasnya, ternyata partai politik yang berasaskan Islam tidak mendapatkan suara yang signifikan dari masyarakat muslim sendiri. Pada Pemilu 1999 hasil suara keseluruhan partai Islam tidak lebih dari 20\%, bila PKB dan PAN digabungkan pun paling-paling hanya sekitar35\%. ${ }^{15}$

Realitas ini tentu saja sebagai pukulan telak terhadap para elit politik Islam yang hendak mengusung syariat ke dalam negara. Karena dengan suara itu, maka sudah tentu perjuangan penegakkan syariat Islam melalui parlemen akan menemui banyak kesulitan. Belum lagi kalau suara di atas dikurangi dengan suara PKB yang sekitar 13\%, diketahui bahwa PKB adalah salah satu partai Islam yang tidak memperjuangkan formalisasi syariatIslam.

Namun demikian, kelompok Islam tertentu masih sangat kuat perjuangannya

\footnotetext{
${ }^{13}$ Dalam undang-undang ini secara eksplisit peran pengajaran agama pada semua tingkat.

${ }^{14}$ Bachtiar Effendi, Islam dan negara, hlm. 273.

${ }^{15}$ Ahmad Zubaidi, "Pil Pahit bagi "Islam Politik", Pelita Bangsa 3 September 1999 dan"Skeptisisme bangkitnya Parpol Islam ” Duta Masyarakat, 3 September 1999.
} 
dalam berupaya mengangkat syariat Islam ke dalam negara.Secara formal perjuangan mereka diwakili oleh partai-partai Islam yang ada di Parlemen. Terlihat jelas dalam dua momentum ST MPR Tahun 2000 dan 2001 yang lalu, dua partai Islam; Partai Persatuan Pembangunan dan Partai Bulan Bintang memperjuangkan untuk masuknya kembali "tujuh kata" tentang syariat Islam dalam Piagam Jakarta. Bahkan secara informal mereka mengkampanyekannya melalui berbagai program yang dimotori oleh beberapa organisasi keagamaan, seperti FPI (Front Pembela Islam), MMI (Majelis Mujahidin Indonesia), KISDI (Komite Solidaritas Islam), Lasykar Jihad Ahlus Sunnah wal-Jamaah dan lain sebagainya.

Yang menarik dicermati adalah adanya pertarungan dua kelompok Islam dalam menyikapi masuknya Islam sebagai idiologi.Dalam logika umum, seharusnya kelompok Islam bersatu dalam mengartikulasikan kepentingan politiknya terutama untuk mengusung syariah menjadi hukum formal di negeri ini. Tetapi mengapa justru kelompok Islam berhadapan satu samalain. Kalau pada masa-masa sebelum era 60-an, barangkali wajar karena yang berhadapan adalam kelompok Islam dan kelompok nasionalis.Tetapi pasca 60-an, petanya berubah total, karena salah satu partai Islam terbesar saat itu, yaitu Nahdhatul 'Ulama (NU), justru memilih berkalaborasi dengan Soekarno.Praktis saja, setelah kolaborasi ini terjadi, sungguhpun ada kelompok Islam yang dekat dengan kekuasaan tetapi gema perjuangan pengusungan syariah ke dalam negara nyaris tak dengarlagi.

Dalam sejarah Indonesia, nampaknya umat Islam selalu disibukkan dengan wacana-wacana teologis yang menghabiskan energi. Sementara persoalan-persoalan pragmatis umat jarang sekali menjadi obyek pembicaraan. Perseteruan dua kubu, antara kalangan Islam yang memperjuangkan Syariat Islam agar menjadi hukum formal bagi umat Islam Indonesia dan kalangan yang menentangnya, telah membuat agenda-agenda keumatan yang pragmatis terabaikan, semisal masalah pendidikan dankesejahteraan.

Dari perkembangan masalah penerapan syari'at Islam di Indonesia adanya pro dan kontra, menjadi latar belakang penulis dan mendorong untuk menulis. Dari sini penulis beri judul: "Implementasi Hukum Islam di Indonesia dalam Perspektif Siyasah Syar'iyah" 


\section{Yurisprudensi Hukum Islam}

Sungguhpun mayoritas penduduk Indonesia beragama Islam, tetapi syariat Islam itu sendiri tidak menjadi landasan legal-formal bangsa Indonesia. Padahal perjuangan menegakkan Hukum Islam sebagai landasan legal-formal itu sendiri sudah mulai sejak saat negeri ini baru mulai akan berdiri. Sampai sekarang, sungguhpun energi umat Islam telah terkuras untuk memperjuangkannya, cita-cita memformalisasikan syariat Islam dalam sebuah sistem kenegaraan belum juga berhasil.

Perumusan kembali cita-cita politik umat Islam itu sendiri harus didasari oleh pemahaman bahwa Islam tidak mewajibkan umatnya untuk mendirikan negara Islam atau memformalisasikan syariat Islam.Hal ini perlu dilakukan agar pergerakan umat Islam dapat lebih leluasa dan tidak terikat dengan formalisme Islam. Karena selama pergerakan Islam dibatasi oleh lebel-lebel formal, maka perjuangan umat Islam hanya akan berkutat di satu tempat saja. Dalam babakan sejarahnya selalu menghadapi konflik idiologis yang justru menyebabkan Islam terpinggirkan dari kancah politik nasional.

Semangat ini didukung kenyataan bahwa dalam ajaran Islam sendiri tidak ada tuntunan yang jelas tentang konstruksi negara Islam atau metode pemberlakuan syariat Islam dalam suatu negara. Al-Qur'an dan As-sunnah lebih banyak memberikan prinsip etis yang relevan tentang cara mengatur masyarakat dan prinsipprinsipnya. Al-Qur'an berulangkali menyebut gagasan normatif tentang musyawarah $\left(\text { syûra }{ }^{16} \text {, keadilan ('adalah) }\right)^{17}$ dan egelitarianisme (musâ wah $)^{18}$.Prinsip-prinsip inilah yang ditunjukkan dalam tradisi politik Islam awal, khususnya pada Nabi Muhammad SAW.

Dengan demikian sudah saatnya, umat Islam tidak lagi bervisi kaku dalam memahami pesan-pesan Al-Qur'an dan As-Sunnah.Umat Islam harus berani menterjemahkan keduanya dalam konteks yang lebih rasional dan berdampak positif terhadap umat Islam.

\footnotetext{
${ }^{16}$ QS. Asy-Syûrâ (42): 38 dan Âli Imrân (2): 159.

${ }^{17}$ QS. Al-Maidah (5): 8 dan An-Nisa (3):135.

${ }^{18}$ QS. An-Nisâ' (4): 1 dan Al-Hujurât (49):13.
} 


\section{Pola Penerapan Hukum Islam di Indonesia.}

Sebelum pemerintahan Belanda, Hukum Islam telah dianut dan dilaksanakan oleh para pemeluknya di Nusantara ini, telah hidup di masyarakat dan menjadi norma serta sumber perilaku.

Kemudian pada zaman penjajahan Belanda, Hukum Islam tetap di akui pada awalnya untuk diberlakukan kepada bumi putera yang bersengketa. Namun pemerintah penjajah Belanda ini dengan memanfaatkan jasa Snouck Hurgronye, berusaha menerapkan berbagai teori untuk merintangi kemajuan Islam di tanah air. Salah satu teori yang populer adalah theory reseptie yang berarti : "Hukum Islam berlaku apabila diterima, atau dikehendaki oleh hukumadat”.

Kebijaksanaan pemerintah Hindia Belanda yang memberlakukan theory Receptie Snouck Hurgronye mendapat reaksi yang keras dari kalangan umat Islam, yang berakumulasi pada perlawanan umat Islam untuk mengusir penjajah dari tanah air Indonesia.

Di masa pendudukan Jepang, tidak ada perubahan berarti mengenai Pengadilan Agama di tanah air sampai Jepang kalah.

Setelah Indonesia merdeka, pengaruh politik PemerintahPenjajah masih berbekas. Ini dapat dilihat dalam penetapan UUD 1945 dan Pancasila sebagai dasar dan falsafah negara, umat Islam harus merelakan penghapusan tujuh kata yang terdapat dalam rumusan Pancasila yang terdapat dalam Piagam Jakarta, karena adanya desakan dari kalangan pihak Kristen. Tujuh kata tersebut dikeluarkan dari Pembukaan UUD 1945, kemudian diganti dengan kata "Yang MahaEsa".

Umat Islam Indonesia telah menerima Pancasila sebagai falsafah bangsa dan ideologi Negara, karena sila-sila Pancasila tersebut tidak bertentangan dengan ajaran Islam. Walaupun konstitusi Negara RI itu Islami, tetapi pelaksanaan Hukum Perkawinan dan Hukum Kewarisan di Indonesia setelah Indonesia merdeka dalam periode 1945-1974, melalui Badan Peradilan Agama tetap tidak berubah seperti sediakala. Baru tahun 1974 dengan disahkannya UU No. 1 Tahun 1974 tentang Perkawinan, teori resepsi kolonial itu menemui ajalnya, karena dengan terbentuknya UU No. 1 tahun 1974 setiap perkawinan harus dilaksanakan menurut hukum agama. Untuk orang Islam, perkawinan baru dianggap sah kalau dilakukan menurut perkawinanIslam. 


\section{Implementasi Hukum Islam dengan Hukum Nasional dalam Sistem Nasional}

Setelah Indonesia merdeka, upaya pembaharuan hukum banyak diarahkan kepada perubahan hukum tertulis peninggalan kolonial untuk dijadikan Hukum Nasional.Hukum Islam dijadikan sebagai salah satu unsur hukum Nasional yang berfungsi sebagai rujukan dalam pembentukan hukum nasional tersebut.Upaya ini telah menghasilkan terbentuknya UU No. 1 tahun 1974 tentang Hukum Perkawinan. Dengan diundangkannya UU No. 1 tahun 1974 tentang Perkawinan yang berlaku bagi semua warga negara Republik Indonesia, maka hukum perkawinan Islam sudah menjadi bagian dari hukum nasional, karena pada tanggal 2 Januari 1974 sudah masuk dalam lembaran Negara. Setelah UU No. 1 tahun 1974 tentang Perkawinan disahkan, maka hukum Fikih Islam telah memasuki fase baru yang disebut fase Taqnin (fase pengundangan).

Walaupun UU No. 1 tahun 1974 tentang Perkawinan telah disahkan, tetapi pelaksanaannya melalui putusan Pengadilan Agama masih harus dikukuhkan oleh Pengadilan Negeri. Tetapi dengan terbentuknya UU No. 7 tahun 1989 Pengadilan Agama sudah disejajarkan dengan Pengadilan Negeri, sehingga putusan Pengadilan Agama tersebut tidak lagi dikukuhkan oleh Pengadilan Negeri. Kemudian, walaupun telah diundangkan UU No. 7 tahun 1987 yang mensejajarkan Pengadilan Agama dengan Pengadilan Negeri, ternyata dalam implementasi hukum Islam di Indonesia masih bermasalah, karena tidak adanya keseragaman para hakim Peradilan Agama dalam menetapkan hukum terhadap persoalan-persoalan hukum perkawinan yang mereka hadapi sering terjadi perbedaan putusan antara satu Peradilan Agama dengan Peradilan Agama yang lainnya, yang dapat mengurangi wibawa Peradilan Agama. Hal ini disebabkan tidak tersedianya kitab materi Hukum Islam yang sama. Dari realitas ini, keinginan untuk menyusun "Kitab Hukum Islam" dalam bentuk kompilasi dirasakan semakin mendesak. Penyusunan kompilasi ini bukan saja didasarkan pada kebutuhan adanya keseragaman referensi keputusan hukum di Peradilan Agama Indonesia, tetapi juga disandarkan pada keharusan terpenuhinya perangkat-perangkat sebuah Peradilan, yaitu kitab Materi Hukum Islam yang digunakan di Lembaga Peradilan tersebut. Itulah yang mendorong pembentukan Kompilasi Hukum Islam (KHI) dengan berdasarkan Perundang-Undangan, seperti UU No. 22 tahun 1946, UU 
No. 32 tahun 1954, UU No. 1 tahun 1974, PP No. 9 tahun 1975 dan PP No. 28 tahun 1977.

Dengan terbentuknya KHI, Fikih Islam, khususnya Fikih Munakahat yang selama ini tidak dipandang sebagai hukum positif walaupun orang-orang Islam telah melaksanakannya sejak masuknya Islam ke Indonesia, telah ditransformasikan menjadi hukum positif, atau sebagai hukum Nasional yang berlaku dan mengikat bagi seluruh umat Islam di Indonesia, melalui Instruksi Presiden (INPRES) No. 1 tahun 1991 yang ditujukan kepada Menteri Agama untuk menyebarluaskannya. Adapun Undang -undang yang disusun dalam materi hukum Islam di antaranya:

\section{Pembentukan UU No. 1 Tahun 1974 TentangPerkawinan}

a. Latar Belakang dan Proses Pembentukan UU No. 1 Tahun 1974 tentang Perkawinan

Lahirnya Undang-Undang Perkawinan yang berlaku bagi semua warga negara Republik Indonesia tanggal 2 Januari $1974^{19}$ sebagian besar telah memenuhi tuntutan masyarakat Indonesia. Tuntutan ini sudah dikumandangkan sejak kongres perempuan Indonesia pertama tahun 1928 yang kemudian susul-menyusul di kedepankan dalam kesempatan- kesempatan lainnya berupa harapan perbaikan kedudukan wanita dalam perkawinan. Perbaikan yang didambakan itu terutama diperuntukkan bagi golongan "Indonesia Asli" yang beragama Islam yang hak dan kewajibannya dalam perkawinan tidak diatur dalam hukum yang tertulis. ${ }^{20}$ Hukum perkawinan orang Indonesia asli yang beragama Islam yang tercantum dalam kitabkitab fikih Islam, menurut sistem hukum di tanah air kita tidak dapat digolongkan ke dalam kategori "hukum tertulis", karena tidak tertulis dalam peraturanperundangundangan. $^{21}$

\footnotetext{
${ }^{19}$ Yang dimaksud dengan Undang-Undang Perkawinan dalam pembahasan ini, ialah segala sesuatu dalam bentuk aturan yang dapat dijadikan petunjuk oleh umat Islam dalam masalah perkawinan dan dijadikan pedoman oleh Hakim di Lembaga Peradilan Agama dalam memeriksa, menyelesaikan dan memutuskan perkara-perkara yang berkenaan dengan perkawinan.

${ }^{20}$ Hukum tertulis lazim disebut sebagai hukum perundang-undangan. Hukum tertulis telah menjadi tanda dari hukum modern yang harus mengatur serta melayani kehidupan modern - Hasanuddin AF (et.al), Pengantar Ilmu Hukum, Jakarta : Pustaka Al-Husna Baru, 2004), hlm, 7.

${ }^{21}$ Mohammad Daud Ali, Hukum Islam dan Peradilan Agama, (Jakarta : Raja Grafindo Persada, 2002), cet. II, hlm, 21.
} 
Menurut Mohammad Daud Ali, masalah-masalah yang menjadi pusat perhatian pergerakan wanita pada waktu itu adalah soal-soal : 1. perkawinan paksa, 2. poligami dan 3. talak yang sewenang-wenang. ${ }^{22}$

Di antara isu yang perlu ditampung oleh pemerintah dalam merumuskan draft undang-undang perkawinan adalah pembinaan hukum nasional dengan melakukan kodifikasi dan unifikasi hukum nasional, masalah kependudukan, hak asasi manusia, pengayoman terhadap martabat wanita dan pembinaan kesejahteraan keluarga, sebagaimana disebutkan dalam risalah sidang pleno DPR tanggal 30 Agustus 1973. ${ }^{23}$

\section{Pembentukan Kompilasi Hukum Islam(KHI)}

\section{a. Latar Belakang dan Proses PembentukanKHI}

Walaupun umat Islam Indonesia telah berhasil melalui Menteri Agama dan para ulama dalam menggolkan RUU PA menjadi Undang- Undang Peradilan Agama No. 7 Tahun 1989, bukan berarti bahwa semua persoalan yang berkaitan dengan implementasi hukum Islam di Indonesia menjadi selesai, karena ternyata persoalan krusial yang dihadapi adalah tidak adanya keseragaman para hakim Peradilan Agama dalam menetapkan hukum terhadap persoalan-persoalan yang mereka hadapi. Sering terjadi perbedaan putusan antara satu Peradilan Agamadengan

Peradilan Agama yang lainnya dalam masalah yang sama, ${ }^{24}$ yang dapat mengurangi wibawa Peradilan Agama. Hal ini disebabkan tidak tersedianya kitab Materi Hukum Islam yang sama. Meskipun telah ditetapkan 13 kitab fikih yang kesemuanya dalam mazhab Syafiei yang dijadikan rujukan dalam memutuskan perkara, akan tetapi tetap menimbulkan persoalan, yaitu tidak adanya keseragaman putusan hukum, karena dalam kitab-kitab fikih tersebut juga terdapat perbedaan pendapat (ikhtilaf), walaupun dalam satu mazhab (mazhabSyafiei 1 ). ${ }^{25}$

Setelah diundangkan PP No. 45/1957 tentang pembentukan PA/Mahkamah Sharieeah diluar Jawa dan Madura, kepala biro PA dan Departemen Agama segera

\footnotetext{
${ }^{22}$ Mohammad Daud Ali, Hukum Islam dan Peradilan Agama, (Jakarta : Raja Grafindo Persada, 2002), cet. II, hlm, 21 .

${ }^{23}$ Risalah sidang Pleno DPR tanggal 17 September 1973, Pandangan Umum Fraksi ABRI.

${ }^{24}$ Karena belum ada KHI, selain tidak seragamnya keputusan hukum untuk masalah yang sama, juga bahkan dijadikan alat politik untuk memukul orang lain yang dianggap tidak sepaham, padahal fikih itu semestinya membawa rahmat, bukan menjadi penyebab perpecahan, - Lihat : Hasan Basry, Perlunya Kompilasi Hukum Islam, Mimbar Ulama, No. 104, Tahun X April 1986, hlm, 60.

${ }^{25}$ Lihat Dirjen Bimbaga Islam, Sejarah Penyusunan Kompilasi Hukum Islam di Indonesia, (Jakarta: Departemen Agama R.I., 1991/1992),hlm, 139.
} 
mengeluarkan surat edaran No. B/1/735 tanggal 15 Februari 1958 yang menganjurkan penggunaan 13 (tiga belas) macam kitab fikih sebagai pedoman. ${ }^{26}$ Ketiga Belas kitab fiqh tersebut adalah : al-Bajuri, Fat al Mu'in berikut Sharahnya, Sharqawi 'ala al Tahrir, al Mahalli, Fath al-Wahhab, Tuhfah, Targhib al-Mushtaq, Qawanin Shar'iyyah lisayyid Usman bin Yahya, Qawanin lisayyid Sodaqah Dakhlan, Shamsuri fil Faraid, Bughyat al-Mastarshidin, al-Fiqh 'ala al Madhahib al-'arba'ah dan Mughny alMuhtaj. ${ }^{27}$

Menurut Sudirman Tebba penggunaan kitab-kitab fikih tersebut dalam memutuskan perkara di Pengadilan Agama itu dianggap terlalu banyak kelemahan, antara lain karena buku rujukan pengadilan agama itu dianggap terlalu banyak, disamping judul bukunya saja ada 13 buah, juga antara judul buku itu ada yang terdiri dari beberapa jilid, akibatnya penggunaannya terasa tidak praktis. ${ }^{28}$

Dengan banyaknya kitab fikih yang dianjurkan oleh Departemen Agama maupun PA, masih sangat mungkin sekali terjadi perbedaan putusan dalam wilayah PA, dikarenakan para hakim bebas menafsirkan ataupun memilih hukum apa yang akan dijatuhkan disebabkan banyaknya rujukan. ${ }^{29}$

Menurut Amiur Nuruddin dan Azhari Akmal Tarigan, berangkat dari realitas ini, keinginan untuk menyusun "kitab hukum Islam" dalam bentuk kompilasi dirasakan semakin mendesak. Penyusunan kompilasi ini bukan saja didasarkan pada kebutuhan adanya keseragaman referensi keputusan hukum di PA di Indonesia, tetapi juga disandarkan pada keharusan terpenuhinya perangkat-perangkat sebuah Peradilan, yaitu kitab materi hukum Islam yang digunakan di lembaga Peradilan tersebut. ${ }^{30}$

\section{Respon dan Penolakan penerapan hukum Islam}

\section{Respon dukungan Penerapan Hukum Islam}

Gerakan ini juga disebut dengan gerakan Formalistik. Secara etimologis adalah berasal dari akar kata formal yangberarti sesuai peraturan yang sah,

\footnotetext{
${ }^{26}$ Dadan Muttaqien, et.al, Peradilan Agama dan Kompilasi Hukum Islam Dalam Tata Hukum Indonesia, (Yogyakarta: UII Press, 1999), cet II, hlm, 53.

${ }^{27}$ Sudirman Tebba (ed), Perkembangan Kontemporer Hukum Islam di Asia Tenggara, (Bandung: Mizan, 1993), cet. I, hlm, 21

${ }^{28}$ Depag RI, Kompilasi Hukum Islam di Indonesia, (Jakarta: Direktorat Pembinaan Badan Peradilan Agama, 2000), hlm, 128.

${ }^{29}$ Masrain Basran, Kompilasi Hukum Islam Mimbar Ulama, No. 105, Tahun X, Mei 1986, hlm, 8,9.

${ }^{30}$ Amiur Nuruddin dan Azhari Akmal Tarigan, Hukum Perdata Islam di Indonesia, hlm, 29.
} 
resmi ${ }^{31}$ berhubungan dengan bentuk, ${ }^{32}$ dan kaku. ${ }^{33}$ Dengan demikian formlistik bisa berarti peresmian atau menjadikan resmi,bersifat apa adanya, sikap yang kaku dan rigid.

Kelompok ini, sebagai mana pendapat Din Syamsudin:

"Mengidam-idamkan terjadinya penyatuan antara agama dan negara,dengan kata lain negara (politik) adalah sebagai bagian yang integral dari agama. dîn (agama) bagi aliran ini mempunyai hubungan yang sangat dekat sekali dengan siyasah (politik). Oleh karena itu umat Islam harus terlibat dalam politik, menegakkan sistem politik Islam, bahkan negara Islam. Mereka cenderung mempertahankan bentuk-bentuk pra konsepsi politik Islam, misalnya pentingnya partai politik Islam formal (menggunakan nama Islam misalnya), ungkapan, idiom-idiom dan simbol-simbol politik Islam, terutama landasan organisasi secara konstitusional adalah Islam.",34

Begitu pula Masykuri Abdillah, juga menuturkan bahwa:

"Ada sebagian aspirasi umat Islam (santri) yang menjadikan Islamsebagai idiologi yang manifestasinya berbentuk pelaksanaan ajaran agama (syariat) secara formal sebagai hukum positif. Oleh karena itu orientasi ini mendukung pendekatan struktural dalam sosialisasi dan institusionalisasi ajaran Islam. Orientasi ini sangat mendukung "Islamisasi” disegala bidang sebagai prioritas utama, sehingga dalam praktiknya hal ini bisa mengurangi hak dan eksistensi non-Muslim.”35

Selaras dengan kedua pendapat diatas adalah pandangan Qadri Azizi, ia menjelaskan bahwa:

\footnotetext{
${ }^{31}$ Departemen Pendidikan dan Kebudayan, Kamus Besar Bahasa Indonesia, BalaiPustaka, Jakarta, 1988, hlm, 244. Lihat pula, Peter Salim , The Contemporary, English-IndonesiaDictionary, Modern English Press, Jakarta, 1986, hlm, 736

${ }^{32}$ Joyce. M Hawkins, Kamus Bahasa Oxford Inggris-Indonesi, Indonesia-Inggris,Erlangga, Jakarta, 1996, h, 131. Lihat pula , Peter Salim, The Contemporary, English-IndonesiaDictionary, hlm,736

${ }^{33}$ Jhon M.Echol dan Hasan Sadzili, Kamus Bahasa Inggris, Gramedia Pustaka Utama,Jakarta, 2000, hlm,254 Lihat pula, Peter Salim, The Contemporary, English-Indonesia Dictionary, hlm,1959

${ }^{34}$ M. Din Syamsuddin, Islam dan Politik Era Orde Baru, (Logos Wacana, Ciputat, 2001),hlm,152 -154

${ }^{35}$ Masykuri Abdillah, Aspirasi Ummat Antara Islamisasi dan Humanisasi, dalam,Kurniawan Zen dan Syarifuddin HA. (edit) Syariar Islam Yes Syariat Islam No, Dilema Piagam Jakarta dalam Amandemen UU 1945, Paramadina, Jakarta, 2001, hlm, 18
} 
"Menurut paham ini hukum Islam harus diterapkan kepada mereka yangsudah mengucapkan dua kalimat syahadah atau sudah masuk Islam, Istilah positivisasi hukum Islam menurut paham ini tidak akan pernah populer kecuali bahwa berarti mereka yang beragama Islam harus serta merta menjalankan atau dipaksakan untuk menerima hukum Islam dalam kehidupan sehari-hari. Oleh karenan itu proses kehidupan politik termasuk partai politik adalah dalam rangka atau sebagai alat untuk menerapkan hukum Islam secara normatif dan formal ini. Konsekuensinya pelaksanaan Piagam Jakarta menjadi persoalan besar dan serius yang harus selalu diperjuangkan, oleh karena merupakan satu-satunya cara untuk penerapan hukum Islam secara formal - kalau perlu dipaksakan - di negara Indonesia. Jika ditarik keatas lagi dari sisi ekstrimitas, pendekatan ini menjadi sekriptualis dan tekstualis yang biasanya kurang mempertimbangkan kontekstual dan lingkungan sosiologis." ${ }^{36}$

Sebagaimana diketahui bahwa pada masa era reformasi ini muncul tuntutan atau aspirasi sebagian kelompok Islam untuk memformalisasikan Piagam Jakarta atau syariat Islam secara keseluruhan. Hal ini ditandai dengan munculnya beberapa Partai Islam yang memiliki platform untuk menjadikan hukum Islam berlaku dalam kehidupan berbangsa dan bernegara Indonesia. Aspirasi ini ternyata diperjuangkan oleh sejumlah partai Islam, terutama PPP, PBB, dan PK dalam perdebatan perubahan (amandemen) UUD 1945 baik yang pertama (1999) maupun kedua (2000) dan ketiga (2002). Namun perjuangan ini tidak berhasil karena tidak didukung oleh mayoritas anggota MPR dan bahkan mayoritas bangsa Indonesia. Meski demikian, platform ini kini tetap menjadi agenda partai-partai itu serta sejumlah ormas-ormas Islam, yang dilakukan secara legal dan konstitusional. ${ }^{37}$

\section{Respon Penolakan Penerapan Hukum Islam (Sekuler)}

Sekularistik secara etimologis berasal dari akar kata sekuler (secular) yang berarti duniawi. ${ }^{38}$ Kemudian secularize berarti memindahkan kepada urusan-urusan kegiatan-kegiatan keduniawian. Sementara John L. Esposito dengan menyitir pendapat Berkeh menuturkan:

\footnotetext{
${ }^{36}$ A. Qodri Azizy, Eklektisisme Hukum Nasional, Kompetisi Antara Hukum Islam danHukum Umum,( Gamma Media, Cet I, Yogyakarta,2002), hlm, 194 -195

${ }^{37}$ Masykuri Abdillah, Demokrasi yang Religius,Membincang Kembali Konsep Demokrasidi Indonesia, hlm, 33. Dalam pidato pengukuhan sebagai Guru Besar di UIN Syarif Hidayatullah,Jakarta, 2004

${ }^{38}$ John M Ecohols dan Hassan Shadily, Kamus Inggris - Indonesia , hlm, 509
} 
"Bahwa secularisme bermakna yang bukan agama. Kata ini berasaldari dunia latin saeculum yang pada mulanya berarti masa atau generasi dalam arti waktu temporel. Kata ini kemudian menjadi bermakna segala hal yang berhubungan dengan dunia ini, yang dibedakan dengan hal sepiritual yang ditunjukkan untuk mencapai surga. Kata Prancis "laicite, juga berarti secularisme, tetapi makna aslinya menunjuk pada pengertian " masyarakat biasa" mereka yang bukan kelompok pendeta." 39

Menurut Abercrambie sebegaimana yang dikutip oleh M. Dawam Raharjo, secularisasi yaitu sebagai "proses" dimana pemikiran praktik dan institusi keagamaan telah kehilangan arti pentingnya. ${ }^{40}$ Sementara Fairchild mendefinisikan bahwa secularisasi adalah:

"Suatu proses dimana struktur sosial yang tadinya tertutup dan sucitelah ditransformasikan menjadi suatu bentuk kontrol dan interaksi yang bukan suci dan terjangkau. Dalam konteks ini sekularisasi bisa bersifat segmental atau sebagian, misalnya. Kehidupan politik suatu bangsa bisa mengalami sekularisasi tanpa menimbulkan pengaruh terhadap kepercayaan indifidual atau sektarian dan kesetiaan kepada lembaga keagamaan tertentu."

Kemudian Nurcholish mencoba menjelaskan tentang perbedaanmendasar antara secularisasi dan sekularisme. Menurutnya :

"Secularisasi ialah bahwa ia adalah proses, yakni prosespenduniawian. Lebih lanjut ia menjelaskan bahwa pengertian pokok tentang sekularisasi adalah pengakuan wewenang ilmu pengetahuan dan penerapannya dalam membina kehidupan duniawi dan ilmu pengetahuan itu sendiri terus berproses dan berkembang menuju kesempurnaannya. Sementara secularisme adalah suatu paham, yaitu paham keduniawian, ia membentuk filsafat tersendiri dan pandangan dunia baru yang

\footnotetext{
${ }^{39}$ John. L.Esposito, The Oxford Encyclopedia of The Modern Islamic World, Vol 4, New York Oxford, Oxford University Press, 1995, h, 20. Dalam kontek sejarah sekularisme atau proses sekularisasi berasal dari pengalaman sejarah Eropa. Hal ini berarti pemisahan secara bertahap " hampir semua aspek kehidupan dan pemikiran dari perkumpulan-perkumpulan keagamaan dan tujuan -tujuan kependetaan," suatu proses yang berkembang di Inggris pada abad ke enambelas dengan peralihan kekuasaan politik dari arena keagamaan kenegaraan dan dalam kasus-kasus hukum dari kehakiman yang religius ke secular.( Sommerville, 1992, h, 112-117). Para sejarahwan mencatat bahwa secularisasi pra Industri mendapat dukungan dari protestan yang mereka definisikan sebagai " menyekularkan agama", yaitu suatu yang menyetujui pemisahan agama dari fungsi-fungsi kenegaraan dalam rangka memurnikannya dengan cara memindahkannya dariwilayah korupsi duniawi. Hingga abad ke sembilan belas kata "secular" tidak untuk mendiskripsikan proses ini. Lihat ,Ibid

${ }^{40}$ Nicholas Abersrambie, et al. The Penguin Dictionary of Sosiology, Penguin Books, 1986, h, 188, sebagaimana dikutip oleh M. Dwam Raharjo, Dalam, Islam dan Modernisasi :Catatan atas Paham Seculariasasi Nurcholish Madjid. Nurcholish Madjid, Islam Kemodernan dan keindonesiaan, Mizan, Bandung, 1987, h, 25

${ }_{41}$ HP. Fairchild and 100 Authorities, Dictionary of Sosiology and Related Sciences, Little field, Adams dan co Inc, 1966, h, 268, sebagaimana dikutip oleh, M.Dawam Raharjo, Ibid.
} 
berbeda, atau bertentangan dengan hampir seluruh agama didunia ini. Nurcholish menegaskan bahwa sekalipun kita mengharuskan adanya secularisasi tetapi dengan tegas kita menolak secularisme."

Dengan demikian sekularistik adalah yang bersifat keduniawian, dalam arti melihat urusan-urusan kegiatan-kegiatan itu hanya bersifatdunawiyah semata (bukan keagamaan). Kemudian menurut Munawir Sadzali sekularisme- dalam pengertian politik praktis -adalah penolakan pada campurtangan negara atau pemerintah di dalam kehidupan keagamaan rakyat dan pada waktu yang sama penolakan terhadap campurtangan tokoh-tokoh atau lembaga-lembaga keagamaan di dalam kehidupan kenegaraan atau politik. ${ }^{42}$

Talal Asad dalam tulisannya "Pemikiran Tentang Sekularisme di Mesir" berpendapat bahwa :

"Sebuah negara yang sekuler adalah sebuah bangunan modern yangdidasarkan pada pembedaan antara hukum publik dan hukum privat, pada suatu tatan politik yang mengharuskan "agama" untuk dimasukkan kedalam bidang privat oleh aturan hukum, pada ideologi individualisme,moral dan penurunan kebermaknaan dari subjek pengetahuan (Manusia), pada penghormatan jasad fisik, serta pada kepekaan rasa pribadi, yang kesemuanya muncul di Eopa Barat bersamaan dengan terbentuknya negara modern. ${ }^{43}$

Sebelum mengelaborasi lebih lanjut pandangan-pandangan kelompok sekularis, sedikit perlu kami singgung di sini posisi dua organisasi Islam terbesar di Indonesia, yakni NU dan Muhammadiyyah. Kajian Islam di Indonesia sebenarnya tidak akan sempurna tanpa mengkaji kedua organisasi tersebut, karena keduanya merupakan mainstream Islam di Indonesia. Hanya saja dalam kajian ini, penulis kesulitan memposisikan kedua organisasi tersebut. Hal ini disebabkan pertama, dalam mensikapi pro kontra penerapan syariat Islam di Indonesia organisasi tersebut tidak mengeluarkan keputusan secara resmi melalui mekanisme organisasi masingmasing. Kedua, terfragmentasikannya pandangan tokoh-tokoh sentral di kedua organisasi tersebut dalam mensikapi penerapan syariat Islam di Indonesia. Sehingga

\footnotetext{
${ }^{42}$ Munawir Sadzali, Negara Pancasila Bukan Negara Agama dan Bukan Negara Sekuler, Ringkasan Ceramah Menteri Agama pada Pekan Orientasi Manggala Bp 7, 12 Juni 1990, di Bogor, Pada, Islam Realitas Baru dan Orientasi Masa Depan Bangsa, UI, Press, Jakarta, 1993, Cet I, h, 82

${ }^{43}$ Talal Asad, Pemikiran Tentang Sekularisme dan Hukum di Mesir, Pada DinamikaKontemporer dalam Masyarakat Islam, Editing, Die Vander Meji, INIS, Leiden Jakarta, 2003Penerjemah, Somardi, h, 85
} 
penulis mengambil kesimpulan bahwa NU dan Muhammadiyyah adalah dua organisasi di Indonesia -yang dianggap sebagai mainstream Islam Indonesia- Secara organisatoris kedua keduanya tidak terlibat secara langsung dalam kancah hiruk pikuknya prokontra penerapan syariat Islam di Indonesia, namun para anggota organisasi tersebut secara indifidu terlibat aktif dalam kancah polemik pro dan kontra tersebut. Sebut saja misalnya Ahmad Syafi'i Maarif (ketua PP. Muhammadiyyah) dan Hasyim Muzadi (Ketau umum PB. NU), namun demikian perlu ditegaskan kembali di sini, meskipun mereka sering melontarkan ide dan gagasannya seputar penerapan syariat Islam di Indonesia modern, namun mereka lebih mengatas namakan pribadi. Itu berarti tidak bisa disamakan anatara visi institusi dengan visi pribadi masing-masing tokoh besar tersebut.

Kembali pada persoalan. Sampai di sini terlihat jelas visi yang di kedepankan kaum formalis sangat lah berlawanan dengan apa yang dipertahankan oleh kaum sekularis. Beranjak dari pemahaman sekularistik sebagimana di atas maka pendukung kelompok ini antara lain adalah : Nurcholish Madjid, Abdurrahman Wahid, Azyumardi Azra, A. Syafii Maarif, Islam Liberal.

\section{Kesimpulan}

Sampai di sini berdasarkan deskripsi dan analisis pada bagian-bagian terdahulu, kiranyabeberapa kesimpulan penting mengenai penelitian ini diantaranya:

1. Hukum Islam adalah Suatu aturan atau norma yang harus di ikuti oleh ummat Islam yang berasal dari Allah swt. Namun sifatnya sesuai dengan perkembangan zaman dan waktu. Adapun Per Istilahannya dikarenakan berbaurnya per istilahan hukum yang di bawah oleh kolonial belanda. Sebagaimana negara-negara di belahan dunia Islam, di Indonesiaproblematika antara syariat dan negara juga telah menjadi masalah yang krusial semenjak para tokoh kemerdekaan (founding fathers) merencanakan untuk mendirikan republik ini pada tahun 1945, kemudian pada sidang-sidang konstituante dari tahun 1956 sampai dengan 1959, berlanjut pada saat sidang MPRS tahun 1966 sampai dengan 1968, hingga sampai pada era reformasi ini.

2. Kelompok formalistik memandang bahwa syari'ah itu adalah agamaitu sendiri sebagaimana arti dasar yang terdapat dalam teks-teks al- Qur'an dan sebagaimana yang didefinisikan oleh banyak ulama. Menurut kelompok ini cakupan syariat adalah sama dengan cakupan agama yaitu menyangkut hukum yang bersifat I'itiqâdiyyah, Khulûqiyyah, 'Ubûdiyyah danMuamalah. 
3. Kemudian menurut pandangan kelompok sekularistik, syarî’ah adalah agama itu sendiri, karena sifatnya yang universal maka tidak boleh di formalisasikan. Pada tataran aplikasinya, syariat hanya dapat dijadikan sebagai sumber etika dan moral saja. Mengenai fiqh atau hukum Islam, menurut kelompok ini, hanya boleh dipraktekkan secara kultural, tidak lebih dari itu. Karena bagi mereka aplikasi syarî’ah melalui jalur positifisi masih menyisakan banyak persoalan. Misalnya :Pertama, konsep Riddah dalam hukum Islam yang dianggap bertentangan dengan kebebasan dan toleransi beragama. Kedua, Konsep Kafir Dzimmi yang dianggap bertentangandengan persamaan hak antar warga negara. Ketiga, konsep kedudukan wanita yang dianggap bertentangan dengan persamaan hak antara pria dan wanita. Oleh karena itu bagi kelompok ini apapun bentuk negara dan undang-undangnya menjadi tidak penting selagi kemaslahatan umum dapat terjamin. barometer kemaslahatan umum dapat dikatakan terjamin menurut kelompok ini adalah jika lima perinsip dasar Maqâshid alSyarî'ah terrealisir.

\section{Daftar Pustaka}

Paparan lebih jauh dapat dilihat dalam Bahtiar Effendi, Islam dan Negara: Transformasi Pemikiran dan Praktik Politik Islam di Indonesia , Jakarta:Paramadina, 1998, cet I

Syaifuddin Anshari, Piagam Jakarta 22 Juni 1945, Bandung: Penerbit Pustaka, 1983, cet. I

Abdurrahman Wahid, Islam, Pluralisme dan Demokrasi, dalam Arief Afandi (ed), Islam Demokrasi Atas Bawah, Jakarta: Pustaka Pelajar, 1996, Cet ke-1

Ahmad Suhelmi, Soekarno versus Natsir, Jakarta: Dar Al-Falah, 1999, cet. I

Endang Syaifuddin Anshari, Piagam Jakarta 22 Juni 1945, Bandung: Penerbit Pustaka, 1983 , cet. II

Robert W. Hefner dalam Ahmad Baso (ed), Civil Islam: Islam dan Demokratisasi di Indonesia, Jakarta: ISAI, 2001.

Ahmad Zubaidi, "Pil Pahit bagi "Islam Politik", Pelita Bangsa 3 September 1999 dan"Skeptisisme bangkitnya Parpol Islam ” Duta Masyarakat, 3 September 1999.

Hasanuddin AF (et.al), Pengantar Ilmu Hukum, Jakarta : Pustaka Al-Husna Baru, 2004. 
Mohammad Daud Ali, Hukum Islam dan Peradilan Agama, Jakarta : Raja Grafindo Persada, 2002, cet. II

Mohammad Daud Ali, Hukum Islam dan Peradilan Agama, Jakarta : Raja Grafindo Persada, 2002, cet. II

Lihat Dirjen Bimbaga Islam, Sejarah Penyusunan Kompilasi Hukum Islam di Indonesia, (Jakarta: Departemen Agama R.I., 1991/1992.

Dadan Muttaqien, et.al, Peradilan Agama dan Kompilasi Hukum Islam Dalam Tata Hukum Indonesia, Yogyakarta: UII Press, 1999, cet II

Sudirman Tebba (ed), Perkembangan Kontemporer Hukum Islam di Asia Tenggara, (Bandung: Mizan, 1993), cet. I

Depag RI, Kompilasi Hukum Islam di Indonesia, (Jakarta: Direktorat Pembinaan Badan Peradilan Agama, 2000

Masrain Basran, Kompilasi Hukum Islam Mimbar Ulama, No. 105, Tahun X, Mei 1986. Joyce. M Hawkins, Kamus Bahasa Oxford Inggris-Indonesi, IndonesiaInggris,Erlangga, Jakarta, 1996, h, 131. Lihat pula , Peter Salim, The Contemporary, English-IndonesiaDictionary.

Jhon M.Echol dan Hasan Sadzili, Kamus Bahasa Inggris, Gramedia Pustaka Utama,Jakarta, 2000, hlm,254 Lihat pula, Peter Salim, The Contemporary, English-Indonesia Dictionary.

M. Din Syamsuddin, Islam dan Politik Era Orde Baru, Logos Wacana, Ciputat, 2001.

Masykuri Abdillah, Aspirasi Ummat Antara Islamisasi dan Humanisasi, dalam,Kurniawan Zen dan Syarifuddin HA. (edit) Syariar Islam Yes Syariat Islam No, Dilema Piagam Jakarta dalam Amandemen UU 1945, Paramadina, Jakarta, 2001.

Qodri Azizy, Eklektisisme Hukum Nasional, Kompetisi Antara Hukum Islam danHukum Umum, ( Gamma Media, Cet I, Yogyakarta,2002.

Masykuri Abdillah, Demokrasi yang Religius,Membincang Kembali Konsep Demokrasidi Indonesia, hlm, 33. Dalam pidato pengukuhan sebagai Guru Besar di UIN Syarif Hidayatullah,Jakarta, 2004

Nicholas Abersrambie, et al. The Penguin Dictionary of Sosiology, Penguin Books, 1986 , 